УДК 159.9.07(072)

doi: 10.15330/ps.10.1.140-148

\author{
Ольга Кочубейник
}

Інститут соціальної та політичної психології НАПН України

kochubeynyk@gmail.com

\title{
КРИТИЧНИЙ ДИСКУРС АНАЛІЗ: ЯК ЗАБЕЗПЕЧУВАТИ РЕПРЕЗЕНТАТИВНІСТЬ КОРПУСУ ТЕКСТІВ?
}

Нині в психології спостерігається тендениія до поширення зони застосування якісних методів дослідження, котрі звертаються до вивчення лінгвістичних репрезентацій соціальної реальності (наративний аналіз, дискурсивний аналіз, конверсаційний аналіз та інші). Ці методи є, безсумнівно, ефективним інструментом психологічних досліджень. Однак необхідним є чітке розуміння можливостей $і$ обмежень використання ичих методів. Статтю присвячено актуальній проблемі оиінювання репрезентативності корпусу текстів, щчо передбачає включення в нього необхідної $і$ достатньої кількості текстів, яка забезпечить вирішення дослідницьких завдань. Поняття репрезентативності висвітлюється під різними кутами зору, після чого робиться висновок, щзо особистість дослідника, який формує корпус текстів, значною мірою впливає на його репрезентативність. Автор наголошує на неможливості складання корпусу текстів, вивільненого від настановлень дослідника, щчо його формував, $і$ вказує на недоліки застосовуваних тактик контролю такого впливу. На основі теоретичного аналізу розкрито роль міждослідницькоі тріангуляиії в забезпеченні репрезентативності корпусу текстів та підвищенні валідності результатів емпіричного дослідження. Авторка підкреслює, щ̧о міждослідницька тріангуляція дає можливість сформулювати концептуальні узагальнення на базі результатів, отриманих різними експертами. Застосування такої тріангулячії як дослідницької тактики, необхідної для формування корпусу текстів, відповідає загальним вимогам якісних досліджень. Наприкіниі авторка формулює питання, які потребують подальшого дослідження в зазначеному напрямку.

Ключові слова: тріангуляція, якісні методи, валідність, корпус, корпусна лінгвістика, репрезентативність.

Постановка наукової проблеми та її значення. Останнім часом критичний дискурс-аналіз усе частіше починає застосовуватися для вивчення локальних сегментів соціальної реальності, експлікуючи через особливості вживання мови як прозорі, очевидні, так і імпліцитні, неявні відносини домінування, дискримінації, влади і контролю, які конструюють певний порядок соціальності. Посилення уваги психологів та соціологів до мовних конвенцій, різних форм мовних і мовленнєвих експлікацій, які оприявнюють соціальні, гендерні, етнічні, професійні та будь-які інші ідентичності та кристалізовані навколо них спільності та ієрархії між ними, привело до того, що нині йдеться про самостійний напрям дослідження, що має свою методологію, простори теоретичних дискусій, критерії верифікації гіпотез та чималий банк емпіричних даних.

Дослідницькою площиною критичного дискурс-аналізу (КДА) постають лінгвістичні репрезентації соціокультурних процесів, внаслідок чого дослідником здійснюється реконструкція «зв'язаності елементів соціальної реальності», виявляються ідеологічні принципи встановлення цієї зв'язаності, що зрештою дає доступ до порядку соціальності, тобто конкретно-історичного суспільного укладу, який включає в себе соціальні практики, розподіл, циркуляцію та відтворення дискурсів, усталені способи соціального привласнення, соціальну ієрархію, критерії належності до спільнот, закріплені в суспільстві. Процедурно КДА постає як сукупність операцій, які в остаточному підсумку дають можливість здійснити дескрипцію, реконструкцію та інтерпретацію порядку соціальності або окремих його фрагментів через вивчення текстів, що створюються у межах цього порядку різнорівневими суб'єктами дискурсу. Своєю чергою це означає загострення методологічної уваги до низки питань, пов'язаних із «зоною релевантності» текстових фрагментів: «Який саме текстовий матеріал слід збирати, описувати, аналізувати, узагальнювати?», «Який ступінь повноти текстового корпусу є необхідним для конкретного дослідження?», «Які обмежувальні критерії слід сформувати для відбору текстів». 
Пошук відповідей на ці питання проблематизовано багатовимірною інтертекстуальністю як основною властивістю лінгвістичної репрезентації соціокультурних процесів. Мова йде про те, що в дискурсивному горизонті суспільства - тобто у всій множині текстів, які циркулюють у ньому, - не існує критичної межі, за якою можна однозначно оцінити належність текстуальної конструкції до певного дискурсивного порядку, жанру, стилю тощо. Здебільшого, обгрунтовуючи «необхідність й достатність» емпіричного матеріалу, дослідник обтічно та розмито посилається на специфіку предмету дослідження або на неформалізованість КДА як дослідницького методу загалом, що робить таку аргументацію доволі дискутивною. Фактично, проблема забезпечення репрезентативності вибірки «на практиці» виявляється однією із найскладніших методичних процедур, а їі вирішення щоразу потребує звернення до методологічних позицій, на яких грунтується КДА.

Аналіз останніх досліджень. Варто відзначити, що теоретичне поле обговорення критеріїв та способів оцінювання якісних досліджень $є$ доволі дискретним, оскільки різні напрями - обгрунтована теорія, феноменологічне дослідження, наративний та дискурсивний аналізи тощо - пропонують свої власні критерії та процедури, тому, з одного боку, ми маємо чималий перелік таких процедур та критеріїв, з іншого - кожен із пунктів цього переліку може бути критикований за недосконалість [8; 9].

Не становить винятку, на наш погляд, і проблематика забезпечення репрезентативності вибіркової сукупності для тих методів, що були запозичені психологією 3 площини лінгвістики. Тому доцільно, на наш погляд, звернутися до досвіду корпусної лінгвістики [3; 6], що розташовує в центрі уваги не мову як систему, а процес змістовного спілкування мовою. Можемо бачити, що репрезентативність корпусу тексту тут, як і в психології репрезетативність вибіркової сукупності, також виступає запорукою адекватності наукового дослідження. Зокрема йдеться про те, що «репрезентативний масив мовних даних за певний період дає можливість вивчати динаміку процесів зміни лексичного складу мови, здійснювати аналіз лексико-граматичних характеристик в різних жанрах і в різних авторів тощо» [3, 152].

I так само тут точаться суперечки 3 приводу того, що саме слід розуміти під репрезентативністю. Так, репрезентативність корпусу текстів висвітлюється як проблема адекватного відображення, адаптації й інтеграції великих масивів текстів або окремих текстових фрагментів в істотно менший за обсягами корпус текстів [3]. Або, наприклад, зазначається, що репрезентативність - не стільки обсяг матеріалу, скільки пропорційність представлення відображуваного фрагменту мовленнєвої дійсності. Тим самим важливим $є$ ретельний відбір текстів «у заданій пропорції», внаслідок чого розробляється ідея типології текстів [1]. Інші уявлення про забезпечення репрезентативності пов'язані з уявленням про неї як про необхідно-достатнє й пропорційне представлення у корпусі текстів різних періодів, жанрів, стилів, авторів [ 10].

На наш погляд, корпусна лінгвістика, що аналізує процеси фіксації й презентації мовної реальності у вигляді текстів, і критичний дискурс-аналіз, який спрямовує свою увагу на процеси фіксації й презентації соціальної реальності як текстуальної конструкції, мають низку спільних методологічних проблем.

Мета статті полягає в ревізії наявних у дослідницькій практиці тактик забезпечення репрезентативності корпусу текстів, визначенні їхніх «сильних» та «слабких» сторін.

Виклад основного матеріалу. Оскільки у полі нашої уваги - проблематика репрезентативності корпусу текстів, то зазначимо принагідно, що вона є актуальною не тільки для КДА, а й для багатьох психологічних досліджень, що грунтують розуміння свого предмету на текстуальній метафорі свідомості. Тому мова може йти про їхні спільні стратегічні та тактичні особливості забезпечення репрезентативності корпусу текстів.

Аналіз згаданих особливостей доцільно розпочати зі згадування тієї кардинальної розбіжності, що є вододілом та причиною жвавих суперечок між «кількісними» та «якісними» дослідженнями. Перші із них, будучи історично першими, міцно закріпили (принаймні, у психології) уявлення про репрезентативність вибіркової сукупності як про 
похідну від випадковості. Численні підручники з експериментальної психології пропонують алгоритми формування репрезентативних вибіркових сукупностей, і ці алгоритми послуговуються ідеєю випадковості добору досліджуваних. Натомість якісні дослідження орієнтуються на протилежний принцип відбору емпіричного матеріалу - на невипадковість добору, що пояснюється особливостями дослідницьких завдань, при вирішенні яких і формувалася їхня методологія. Такі дослідження спрямовують увагу на унікальність соціальних ситуацій чи особистісного досвіду, на практики локальних спільностей, меншин тощо, тобто феноменів, процесів чи ефектів, що у принципі не можуть бути масово розповсюдженими, а отже - проходити крізь віяло випадковості. Наприклад, теоретична вибірка потребує відбору ситуацій, найбільш значущих, найбільш істотних для певної досліджуваної проблеми, «насичених» нею, а репрезентативність даних забезпечується їхньою релевантністю й вагомістю внеску у досліджуваний процес. Для вибірки екстремальних випадків, відповідно, обиратимуться випадки, які дадуть можливість отримати інформацію про «крайні прояви» аналізованого феномену, тоді як вибірка типових випадків, навпаки, формується дослідником з урахуванням того, що, на його погляд, $\epsilon$ звичним, типовим. Ще один шлях формування вибіркової сукупності презентує вибірка критичних випадків, тобто таких, де зміст досліджуваного фрагменту соціальної реальності постає через аналіз «тестових» його виражень («якщо сенс реформ не сприймає найбільш освічена частина спільноти, то решта також їх не сприйматиме»). У всіх згаданих прикладах репрезентативність визначається не рівною для всіх елементів генеральної сукупності ймовірністю потрапити до вибіркової сукупності, але ретельним цілеспрямованим відбором одиничних випадків, які чітко й строго відповідають заданим критеріям.

Означені особливості стратегії якісної методології зумовлюють численні тактичні складності реалізації окремих дослідницьких завдань. Приміром, для сукупності методів, емпіричним фундаментом котрих є текстуальні конструкції (наративний аналіз, дискурсаналіз, конверсаційний аналіз тощо), одним із найважливіших аспектів є процедурне забезпечення репрезентативності корпусу текстів. У найбільш загальному вигляді особливості згаданих методів пов'язані з необхідністю вирішення низки специфічних проблем, a саме: 1) формуванням чітких уявлень про те, яка саме текстуальна конструкція відповідає предмету та меті дослідження, тобто формуванням уявлення про «еталонний» або «зразковий» текст та його властивості); 2) фрагментацією текстуального потоку на певні класи відповідно до цих уявлень (а отже, постає проміжне завдання: формулювання диференційних критеріїв належності до того чи того класу; 3) відбором фрагментів, релевантних виокремленим критеріям («еталонам»); а надалі - здійсненням власне процесу аналізу, тобто осмисленням, тлумаченням та інтерпретацією відібраних фрагментів $[4 ; 13]$.

Таким чином, наріжним каменем постає необхідність формування дослідницького корпусу текстів, тобто сукупності текстів, призначеної не просто для прочитування (в цьому, як зазначають лінгвісти, полягає принципова відмінність «корпусу» від «бібліотеки»), а для вивчення відповідно до мети та завдань дослідження. I тут, на наш погляд, потрібно звернути увагу на два аспекти його побудови. Перший із них стосується того очевидного факту, що механічно утворена множина текстів, сформована, наприклад, за наявністю ключових слів, не гарантує адекватного відображення ані порядку дискурсу, ані - відповідно - порядку соціальності. Тому, організуючи корпус, дослідник повинен орієнтуватися на його «дефрагментацію», тобто на те, щоб в остаточному підсумку відібрані для аналізу фрагменти репрезентували певну цілісність. Фактично, це означає, що формування репрезентативного корпусу тексту обумовлене необхідністю вхоплення деякої «центральної тенденції» того чи того дискурсивного порядку. Другий аспект стосується того, в корпусі повинні бути представлені не просто «зразки» нарацій або інших текстуальних конструкцій, які у максимальному ступені репрезентують певні уявлення про порядок соціальності (ту саму щойно згадану центральну тенденцію), а 
якомога більша кількість «варіантів» таких репрезентацій, включаючи ті 3 них, які $\epsilon$ «периферією» аналізованого порядку соціальності, тобто $є$ факультативними або винятковими версіями цієї соціальності (факультативні тенденції). Отже, одним із тактичних прийомів забезпечення репрезентативності корпусу текстів, який, до речі, не дуже часто обговорюється в літературі, є поєднання центральних та факультативних тенденцій. Методично це означає, що вже на етапі формування корпусу здійснюється первинна інтерпретація й виокремлення силових позицій фрагментів тексту, що до нього входитимуть. (Як буде показано далі, це спричинюватиме ще один шар методологічних проблем).

Серед інших тактичних прийомів можна назвати експозицію соціорелевантних параметрів корпусу текстів. Наприклад, «мемуарні тексти, написані жінками про другу світову війну в період 1960-1970-х років німецькою мовою» [12, с. 143]. Відповідно, це потребує від дослідника визначення та формулювання критеріїв відбору текстових фрагментів, необхідних для дослідження (жанрових, гендерних, часових, мовних тощо), а також маркерів, за допомогою яких він ідентифікуватиме наявність цих параметрів у тексті.

Орієнтуючись на наявний банк робіт, можна створити допоміжний перелік тих критеріїв, які найчастіше застосовуються нині у площині соціальних досліджень. Найчастіше, на наш погляд, використовуються змістові «фільтри», а саме: тема (театральний дискурс, спортивний дискурс), подія (кримський дискурс), жанр (новинний дискурс), ідентичність (молодіжний дискурс, жіночий дискурс), тональність (агресивний дискурс, іронічний дискурс), прецедентна фігура (дискурс персони або «про персону»), стиль (публіцистичний дискурс); спрямованість (загальний дискурс, спеціалізований дискурс); призначення (переконувальний дискурс, розважальний дискурс), «географія» (регіональний дискурс), формат (оприлюднений через 3МІ/ оприлюднений у соцмережах); «сцена» (в межах певної установи, закладу).

Менш уживаним, але також доволі популярним, $є$ застосування темпорального фільтру. Мова може йти про корпус текстів, що породжується навколо певної події (виборчі перегони); відповідно, «часовий вимір корпусу» - це період породження, піку та спаду генерування текстів. Іншим прикладом $\epsilon$ дослідження трансчасових ефектів соціальної реальності, таких як атеїзм, релігійність, фемінізм, сексизм тощо, основною властивістю яких $є$ розвій релевантного текстуального корпусу протягом тривалого періоду. У таких дослідженнях формування корпусу спирається на 1) критичні точки, тобто появу програмних текстів, які значною мірою змінювали аналізований дискурс, привносячи нові ідеологем або створюючи нові силові позиції та силові лінії, 2) пролонгованість, тобто встановлення певного часового кроку (приміром, 10 років, 50 років), i в такому разі аналізуються тексти, що породжувалися у цих зонах.

Дотримання принципу експозиції соціорелевантних параметрів корпусу текстів має своєю перевагою те, що водночас «контролюється» валідність фрагментів, що входять до його складу. 3 іншого боку, постає проблема вираженості маркерів, а отже, проблема оцінювання ступеню насиченості тексту елементами, які необхідними чином презентують дискурсивний (або соціальний) порядок.

Іноді для забезпечення репрезентативності корпусу текстів застосовують такий тактичний прийом, як збалансованість, тобто рівномірну представленість у корпусі текстів різного - за обраним критерієм - змістового наповнення. Іншими словами, мова йде про збалансоване представлення у корпусі різних форматів, жанрів, стилів, «географії» тощо. І основним аргументом на користь такого розв'язання проблеми $\epsilon$ посилання на те, що, оскільки корпус $є$ масштабованою моделлю дискурсивного простору, то в ньому - відповідно до масштабу - пропорційно повинні бути представлені обрані виміри текстуальних конструкцій.

Однак, на наш погляд, ця тактика також не є бездоганною. Наразі зазначимо, що вона дещо нагадує запозичення з кількісних досліджень, в яких репрезентативність вибіркової сукупності (наприклад, стратифікованої) оцінюється через співвіднесення з генеральною 
сукупністю й зазначається, що точні параметри «страт» останньої невідомі. На наш погляд, те саме ми можемо говорити й стосовно дискурсивного горизонту: його організація загалом невідома. А спроба його структурувати тим чи тим чином наражається на неможливість строгої - побудованої на єдиній підставі - класифікації дискурсів. (Нині існує незамкнута, постійно поповнювана множина типологій дискурсів, що виокремлюються різними вченими. I, що ймовірно, ця множина буде збільшуватися. Загальновизнаним, напевно, можна вважати тільки поділ дискурсів на інституційні та неінституційні). Відсутність єдиної системи класифікації текстів, яка необхідна для встановлення збалансованості корпусу, своєю чергою, спричинює ризики того, що 1) будь-яка (жанрова, стилістична) класифікація текстів, представлених у корпусі, не буде беззаперечною; 2) розмитість кордонів між класами продукуватиме ненадійність результату класифікації; 3) «накладання» критеріїв класифікації текстів один на один призводитиме до подвійності (або загалом множинності) атрибуції. Отже, збалансованість як міра оцінки репрезентативності корпусу текстів, хоча й виглядає привабливо, проте також складно реалізована на практиці.

Наступний тактичний прийом, що зустрічається у літературі, - звернення до кількісних параметрів забезпечення (й оцінювання) репрезентативність корпусу текстів. Спрощеною аргументацією доцільності його використання є припущення: що більшим за обсягом $є$ корпус, то вищою $є$ ймовірність представленості в ньому всіх можливих ефектів та дискурсивних подій. Однак, зрозуміло, великий обсяг корпусу обертається часовими затратами на аналіз, що здебільшого поєднується зі зниженням якості останнього, а також створює ризик - особливо для початківців - вийти за межі методу й перетворити його на контент-аналіз.

Певним компромісом між «кількістю та якістю» $є$ використання показників насиченості вибірки [11] . Зокрема, йдеться про те, що збір емпіричного матеріалу слід припиняти тоді, коли вдається створити несуперечливу, економну концепцію, аргументовану фактичним матеріалом. Збір останнього слід припиняти тоді, коли він не вносить змін у концепцію, не приводить до утворення нових смислів, а замість цього «обтяжує» теоретичну конструкцію додатковими (вторинними, несуттєвими) подробицями, - тобто тоді, коли надмірно дрібні, незначні деталі замість поглиблення пояснювальної спроможності теорії - створюють «шуми та перешкоди». Репрезентативність вибірки (йдеться про корпус текстів) пропонують оцінювати за таким показником, як «зміна відносної частоти певної одиниці аналізу при збільшенні вибірки»: якщо відносна частота їі появи від додавання кожного наступного фрагмента тексту буде змінюватися все менше і менше, то можна говорити про те, що ії насиченість забезпечено, а корпус слід вважати репрезентативним.

Однак, на наш погляд, застосування кількісних показників як аргументації репрезентативності корпусу текстів, хоч і $є$ частково виправданим, проте перебуває у суперечності 3 унікальністю випадків, які презентують той чи той порядок соціальності. Доцільніше говорити про те, що обсяг корпусу може варіювати від одиничного фрагмента до їх серії: головним $\epsilon$ те, що цей обсяг повинен забезпечити формулювання беззаперечних висновків (виокремлення фактів, ефектів, тенденцій тощо). Крім того, слід пам'ятати, що прозорість дослідницького процесу є однією з умов забезпечення об'єктивності отриманих результатів, а демонстрація «насиченості» у публікаціях виявляється насправді проблематичною, адже одиниць аналізу буває декілька, що робить оприявнення розлогими й неефективними.

Перераховані тактичні прийоми - представленість центральних та факультативних тенденцій, експозиція соціорелевантних параметрів, збалансованість, кількісні оцінювання - мають спільну рису: вони розташовують основний акцент вирішення проблеми репрезентативності у площину «корпус текстів - дискурсивний горизонт». Іншими словами, хоча ці тактики розроблялися як вдосконалення тих чи тих «якісних» методів, їхнім стрижнем є уподібнення до критеріїв досліджень, здійснюваних за природничо- 
науковим еталоном: частка об’єктивної реальності має відповідати властивостям усієї об'єктивної реальності.

А це породжує, на наш погляд, прогалину між ідеєю та ії реалізацією. Адже основний методологічний зсув, який відбувся в соціогуманітарному пізнанні завдяки оформленню якісних досліджень, пов'язаний зі зміною статусу суб'єктивності у дослідженні: суб'єктивність постає як чутливість, спроможна забезпечити надійність та валідність дослідження, як дослідницький інструмент, який забезпечує можливість «занурення» в соціокультурні практики спільноти, розуміння викристалізуваних у їхньому середовищі аксіологічних, мотиваційних, емоційних та будь-які інших конструктів й ретрансляції їхнього сенсу в науковий дискурс.

Власне, тому в рамках якісних методів розробляються тактичні прийоми забезпечення репрезентативності корпусу текстів, що покладаються саме на суб'єктивність у різних форматах іiі втілення. Остання може фігурувати як інтуїція, дискурсивна компетентність або теоретична чутливість i, зважаючи на міру розвиненості, дослідник повинен ухвалити рішення про включення певного фрагменту до корпусу. I навіть якщо він жорстко дотримуватиметься критеріального відбору текстів (наприклад, за прецедентною персоною), орієнтуючись на грунтовно розроблений перелік маркерів, то навіть у такому разі добір все одно супроводжуватиметься мінімальною інтерпретацією тексту, яка $\epsilon$ невід'ємною часткою процесу експлікації необхідних параметрів заданої соціальної ситуації (про що згадувалося повище). Ба більше, при проведенні КДА дослідникові доволі складно дотриматися вимоги об'єктивної наукової відстороненості, особливо в тому іiі розумінні, якого вимагає класичнонаукова раціональність. Адже дискурсивний фрагмент (текст) - якщо він дійсно є валідним - неодмінно виявиться агональним, «пенетрувальним», таким, що «братиме у полон», тобто викликатиме пристрасність ще в момент першої взаємодії дослідника й тексту (який, за задумом, він мав би читати відсторонено та розсудливо). У методологічних критиках зазначається, що дослідницьку оптику можуть істотно затьмарити надмірні заглибленість і відданість ідеї, яка центрує дискурс (адже кожен дискурс - це обстоювання й конструювання ідеї). Фактично, відстороненість заради об'єктивності стає неможливою у разі агональності дискурсивного фрагмента: останній буде або «pro», або «contra» особистих поглядів дослідника, а тому, вивчаючи, наприклад, практики «дискримінації чоловіків», дослідник (незалежно від своєї статі) неуникненно опиниться на одному з полюсів, що поставить під загрозу репрезентативність сформованого ним корпусу текстів.

Як одну із процедур контролю такої заангажованості, захопленості, пропонують рефлексію авторської позиції, зокрема останнім часом стали популярними дискусії навколо можливостей автоетнографії як «співвіднесення індивідуального досвіду 3 соціальним контекстом, спроба заглянути всередину себе, щоб зробити узагальнення» [2, с. 6]. Проте гіпертрофовані форми надто відвертого самозаглиблення («погана автоетнографія») також виявлятимуться перешкодою, а критеріїв «гарної автоетнографії» не існує. Отже, саморефлексивність - у будь-яких іï форматах - також не є надійним інструментом забезпечення репрезентативності корпусу текстів.

Принагідно зазначимо, що ці тактичні прийоми - інтуїція, теоретична чутливість, дискурсивна компетентність, рефлексивна позиція, автоетнографія - мають іншу спільну рису: вони розташовують основний акцент вирішення проблеми репрезентативності у площину «корпус текстів - суб'єктивність дослідника». I - підкреслимо - «окрему» суб'єктивність.

Натомість більшість якісних методів, особливо ті з них, що працюють із лінгвістичними репрезентаціями соціальної реальності, наголошують на реконструюванні спільно поділюваних смислів. А отже, на наш погляд, інструмент забезпечення репрезентативності корпусу текстів повинен також належати до площини інтерсуб'єктивності. I якщо для верифікації результатів, наприклад, глибинного інтерв'ю, пропонується комунікативна валідізація [5], то для прийняття висновку про репрезентативність корпусу текстів 
єдиною процедурою, яка є релевантною до такої умови, є процедура міждослідницької тріангуляції, тобто комунікація у межах дослідницької групи, яка, фактично, означатиме співавторство (інтерсуб'єктивність) укладання корпусу текстів. У такому разі, на наш погляд, зростатимуть шанси отримати корпус текстів, який матиме високий ступінь репрезентативності завдяки наростанню «гетерогенності суб'єктивностей», які, проте, дійшли згоди стосовно змісту окремого фрагменту лінгвістичної репрезентації соціальної реальності. Отже, репрезентативність корпусу текстів найбільш адекватно до ідеї якісних методів забезпечується процедурами міждослідницької тріангуляції: корпус складається кількома дослідниками, що мають спільно сконструйовану й вербалізовану картину досліджуваної реальності, внаслідок чого сам корпус «контролюється» інтерсуб'єктивністю.

Висновки і перспективи подальших досліджень. Розглянувши різні тактики забезпечення репрезентативності корпусу текстів, можемо сформулювати деякі підсумки. Як було показано, в рамках якісної методології також доволі поширеним є тлумачення репрезентативності як властивості вибіркової сукупності відтворювати значущі параметри генеральної сукупності. Тому значна кількість пропонованих тактик ії забезпечення (представленість центральних та факультативних тенденцій, експозиція соціорелевантних параметрів, збалансованість, кількісні оцінювання) походить 3 необхідності узгодити «корпус текстів» 3 «дискурсивним горизонтом», що породжує таке розуміння репрезентативності, як здатність обмеженої кількості текстів, відібраних згідно з установленими критеріями, у задовільному для мети дослідження ступені відображати закономірності дискурсивного вживання, що характеризують дискурс загалом.

Однак акцентування уваги на тому, що вже на етапі відбору текстових фрагментів неуникненно відбувається їхня інтерпретація, призвело до необхідності формувати тактики, які враховують, що репрезентативність корпусу текстів зазнає значного впливу 3 боку «особистості» дослідника (його інтуїції, дискурсивної компетентності, теоретичної чутливості тощо). Вплив суб'єктивності (як досвіду дослідника) може бути помічений, наприклад, як ризик дисбалансу різного роду (жанрових, стильових, географічних тощо) текстів, як розроблення списку маркерів та, своєю чергою, відсівання маркованих фрагментів, як результат перевірки відповідності тексту дискурсивним вимогам до корпусу та у багатьох інших процедурних моментах.

Звернімо увагу на те, що у кількісних дослідженнях суб'єктивність як досвід дослідника також виявляється неабияким регулятором надійності та валідності отриманих результатів. Адже, приміром, добір діагностичного інструментарію чи вибір статистичних критеріїв в остаточному підсумку є результатом того ж таки досвіду дослідника, його інтуїції, проте це може істотно позначатися на отриманих результатах. (Хоча скрізь стверджується, що вплив дослідника на результати еліміновано). Якісна стратегія визнає принципову неможливість виключити вплив досвіду на результат, а тому суб' єктивність (рефлексивність) дослідника і його здатність розуміння смислів, яким наділені дії й предмети соціальної реальності, позиціонується як інструмент дослідження, який - за умови некоректного поводження із ним - призведе до конструювання іншого, аніж окреслений метою дослідження, порядку соціальності.

Менш поширеними є тактики, пов'язані з перенесенням забезпечення репрезентативності корпусу текстів у площину інтерсуб' єктивності. Процедура міждослідницької тріангуляції, грунтована на використанні й узгодженні соціальних конотацій та факультативних прочитувань текстів, убезпечує від одностороннього впливу окремої суб'єктивності. Однак цей грунт, будучи різним для різних дослідників, що займаються КДА, актуалізує, своєю чергою, проблему формування дослідницької групи, в межах якої буде забезпечено гетерогенність осмислення, тлумачення та інтерпретації відібраних фрагментів: яким саме повинен бути склад цієї дослідницької групи? За якими соціальними, демографічними, освітніми тощо характеристиками вона повинна формуватися, адже предмет аналізу в КДА, очевидно, є чутливим до означених особливостей? 
I наразі маємо ще одну проблему: як визначити, наскільки вчений є тим «репрезентантом фрагменту соціальної реальності», яку він досліджує?

1. Ганиева, И. Ф. (2007). Об использовании корпусов в лингвистических исследованиях. Вестник Башкирского университета, 12, 4, 104-106.

2. Готлиб, А. С. (2004). Автоэтнография (разговор с самой собой в двух регистрах). Социология: 4М,

3. Захаров, В. П. (2016). Пролегомены к корпусной лингвистике. Collegium. Bопросы психолингвистики, 2, 150-161.

4. Іванов, О. В. (2013). Кількісний аналіз тексту чи продукування числових артефактів: аудит контент-аналітичних досліджень. Наукові записки НаУКМА. Соціологічні науки, 148, 11-15.

5. Квале, С. (2013). Исследовательское интервью. М.: Смысл.

6. Кошарная, Г. Б., Кошарный, В. П. (2016). Триангуляция как способ обеспечения валидности результатов эмпирического исследования. Общественные науки. Соииология, 2 (38), 117-122.

7. Мамонтова, В. В. (2010). Корпусная лингвистика в современной парадигме. Актуальные вопросы современной науки, 12, 230-238.

8. Мельникова, О. Т., Хорошилов, Д. А. (2014). Современные критериальные системы валидности качественных исследований в психологии. Национальный психологический журнал, 2(14), 34-46.

9. Мельникова, О. Т., Кричевец А. Н., Гусев А. Н., Хорошилов Д. А., Ф. И. Барский (2014). Критерии оценки качественных исследований. Национальный психологический журнал, 2(14), 47-49.

10. Рыков, В. В. (2002). Корпус текстов как реализаиия объектно-ориентированной парадигмы. М.: Наука.

11. Страусс, А., Корбин, Дж. (2001). Основы качественного исследования: обоснованная теория, процедуры и техники. М.: Эдиториал УРСС.

12. Чернявская, В. Е. (2017). Методологические возможности дискурсивного анализа в корпусной лингвистике. Вестник Томского государственного университета. Филология, 50, 135-148.

13. Чучвара, А. (2015). Формування методології дослідження політичного дискурсу в Україні: практика використання контент-аналізу. Мова і суспільство, 6, 23-34.

\section{REFERENCES}

1. Ganieva, I. F. (2007). Ob ispolzovanii korpusov v lingvisticheskih issledovaniyah [On the use of corpora in linguistic studies]. Vestnik Bashkirskogo universiteta [Bulletin of the Bashkir University], 12, 4, 104-106. (rus.).

2. Gotlib, A. S. (2004). Avtoetnografiya (razgovor s samoy soboy v dvuh registrah) [Autoethography (conversation with itself in two registers)]. Sotsiologiya: 4M. [Sociology: 4M], 18, 5-15. (rus.).

3. Zaharov, V. P. (2016). Prolegomeny k korpusnoy lingvistike [Prolegomena to Corpus Linguistics. Collegium [Collegium], 2, 150-161. (rus).

4. Ivanov, O. V. (2013). Kilkisnyi analiz tekstu chy produkuvannia chyslovykh artefaktiv: audyt kontentanalitychnykh doslidzhen [Quantitative text analysis or producing of numerical artifacts: content analytical studies evaluation]. Naukovi zapysky NaUKMA. Sotsiolohichni nauky [NaUKMA Research Papers. Sociology], 148, 11-15. (ukr.).

5. Kvale, S. (2003). Issledovatelskoe intervyu [Research interview]. Moscow, Smysl Pbl. (rus.).

6. Kosharnaya, G. B., Kosharnyy V. P. (2016). Tryanhuliatsyia kak sposob obespechenyia valydnosty rezultatov эmpyrycheskoho yssledovanyia [Triangulation as a means ensuring validity of empirical study results]. Obshchestvennye nauki. Sotsyologiia [ Social sciences. Sociology], 2 (38), 117-122. (rus.).

7. Mamontova, V. V. (2010). Korpusnaya lingvistika $\mathrm{v}$ sovremennoy paradigme [Corpus linguistics in the modern paradigm] Aktualnyie voprosy sovremennoy nauki [Actual problems of modern science], 12, 230-238. (rus.).

8. Melnikova, O. T., Krichevets A. N, Gusev, A. N., Busygina, N. P., Khoroshilov, D. A., Barskiy, P. I. (2014). Kriterii otsenki kachestvennych issledovaniy [ Criteria for evaluating qualitative research]. Natsionalnyiy psihologicheskiy zhurnal [National Psychological Journal], 2 (14), 47-49. (rus.).

9. Melnikova, O. T., Khoroshilov, D. A. (2014). Sovremennye kriterialnye sistemy validnosti kachestvennykh issledovanii $\mathrm{v}$ psykhologii [Modern criteria system of identifying the validity of qualitative research in psychology]. Natsionalnyiy psihologicheskiy zhurnal [National Psychological Journal], 2 (14), 34-46. (rus.).

10. Rykov, V. V. (2002). Korpus tekstov kak realizatsiya obektno-orientirovannoy paradigmy [The Corpus of Texts as a Realization of the Object-Oriented Paradigm]. Moscow: Science Pbl. (rus.).

11. Straus, A., Corbin, J. (2001). Osnovy kachestvennogo issledovaniya: obosnovannaya teoriya, protseduryi i tehniki [Basics of qualitative research: sound theory, procedures and techniques]. Moscow: Editorial URSS. (rus.).

12. Chernyavskaya, V. E. (2017). Methodological possibilities of discursive analysis in corpus linguistics [Towards methodological application of discourse analysis in corpus-driven linguistics]. Vestnik Tomskogo gosudarstvennogo universiteta. Filologiya [Tomsk State University Bulletin. Philology], 50, 135-148. (rus.).

13. Chuchvara, A. (2015). Formuvannia metodolohii doslidzhennia politychnoho dyskursu v ukraini: praktyka vykorystannia kontent-analizu [Formation of research methodology of political discourse in ukraine: practice of content analysis using]. Mova i suspilstvo [Language and society], 6, 23-34. (ukr.). 


\section{Olga Kochubeynyk \\ CRITICAL DISCUSSION ANALYSIS: HOW TO ASSURE THE REPRESENTATIVITY OF THE TEXT CORPUS?}

Nowadays, qualitative methods of research that deal with the study of linguistic representations of social reality (narrative analysis, discursive analysis, conversive analysis etc) are becoming more and more widespread in pshychology.

These methods are an efficient instrument of psychological research. However, researcher should clearly understand the possibilities and limits of application of such methods. The article addresses the current problem of evaluation of representativeness of the text corpuses. The requirement to representativeness of a text corpus implies the presence of the necessary number of texts that are enough to solve the research problems. Representativeness is viewed in various aspects and conclusion is made that reseacher's personality (who is a corpus builder) has direct impact onto representativeness of a corpus. This impact is further analyzed different aspects producing a justified statement that no corpora may be compiled free of author's view. On the basis of the theoretical analysis, the authors have revealed the role of triangulation in ensuring the representativeness of the text corpus and improving validity of empirical study results. The author emphasizes that investigator triangulation makes it possible to formulate conceptual generalizations based on the results that are obtained by different experts. Applying of triangulation as a investigator tactic is necessary for the formation of a text corpus. Prospective trends for development in this area are provided.

Keywords: triangulation, qualititative methods, validity, corpus, corpus linguistics, representativeness. 